\title{
Waxy maize, corn and cassava starch: thermal degradation kinetics
}

\section{Amidos ceroso, milho e Mandioca: cinética de degradação térmica}

\author{
Aline Merci ${ }^{1}$; Suzana Mali²; Gizilene Maria de Carvalho ${ }^{3}$
}

\begin{abstract}
The use of starches in food and materials areas requires processing at elevated temperatures. The study of thermal degradation kinetics of starches and their relationship with amylose content, crystallinity, viscosity and thermal properties can help to design the processing conditions. The crystallinity and ordering of corn, cassava and waxy maize starches determined by means of X-ray diffraction (XRD) and Fourier Transform infrared spectroscopy (FTIR), respectively. Correlation between crystallinity, viscosity and amylose content was found. The kinetic parameters (activation energy $\left(E_{a}\right)$, order and pre-exponential factor $(A)$ ) were determined through three models: Coats-Redfern, Broido and van Klevelen, using the best linear fit method. The overall order of thermal degradation process of all the starches was found to be of first order. The Ea increases following the order: corn < cassava < waxy maize. The higher $A$ and $E_{a}$ values found for waxy maize starch indicate that structural differences influence the thermal degradation process.
\end{abstract}

Keywords: Content. Intrinsic viscosity. Activation energy. Starches.

\section{Resumo}

$\mathrm{O}$ uso de amidos na área de alimentos e materiais requer processamento a temperaturas elevadas. $\mathrm{O}$ estudo da cinética de degradação térmica dos amidos e sua relação com o teor de amilose, cristalinidade, viscosidade e propriedades térmicas podem ajudar a projetar as condições de processamento. A cristalinidade e o ordenamento de amidos de milho, mandioca e ceroso foram determinados por difração de raios X (DRX) e espectroscopia no infravermelho por transformada de Fourier (FTIR), respectivamente. Correlação entre cristalinidade, viscosidade e teor de amilose foi encontrada. Os parâmetros cinéticos (energia de ativação $\left(E_{a}\right)$, ordem e fator pré-exponencial $\left.(A)\right)$ foram determinados através de três modelos: Coats-Redfern, Broido e van Klevelen, utilizando o método de melhor ajuste linear. A ordem global do processo de degradação térmica de todos os amidos foi determinada como de primeira ordem. $\mathrm{O}$ valor da Ea aumenta seguindo a ordem: milho $<$ mandioca $<$ milho ceroso. Os maiores valores de $A$ e $E_{a}$ encontrados para o amido ceroso indicam que as diferenças estruturais influenciam o processo de degradação térmica.

Palavras-chave: Teor de amilose. Viscosidade intrinseca. Energia de ativação. Amidos.

\footnotetext{
${ }^{1}$ Me., Dpto. Química, UEL, Londrina, Pr, Brasil; E-mail: aline.merci@gmail.com

${ }^{2}$ Dra. Profa., Dpto. Bioquímica e Biotecnologia, UEL, Londrina, Pr, Brasil; E-mail: smali@uel.br

${ }^{3}$ Dra. Profa., Dpto. Química, UEL, Londrina, Pr, Brasil; E-mail: gizilene@uel.br
} 


\section{Introduction}

The search for materials from renewable sources and fully degradable to replace materials obtained from petroleum is a necessity when considering the environmental impact, human health and bioaccumulation potential of its degradation products in the environment. Among the materials considered to replace synthetic plastics, starch has advantages because it is a low-cost and abundant product, with different characteristics depending on its source of production. The production of maize and cassava starch corresponds to approximately $80 \%$ of the world starch production. Brazil is the third largest producer of corn in the world and the fourth largest producer of cassava. Amylopectin is the major component of starch grain and has a low rate of retrogradation and higher paste and gel clarity compared to amylose. These properties make waxy starches attractive to the food industry, encouraging studies aimed at clarifying the influence of structure on the properties of these starches (REIS et al, 2018; MERCI et al., 2019).

Food and thermoplastic materials, blends and composites using starch as feedstock by conventional industrial processing require relatively high temperatures. Depending on processing time and temperature, the degradation of the material can occur to a lesser or greater extent, compromising the physical, organoleptic and mechanical properties of the product. Studies on the thermal degradation mechanism of starch and how the extent of thermal degradation is influenced by the amylose content, molecular weight, crystallinity and ordering are important to define the processing conditions and the technological applications of the product (LIU et al., 2010).

The process of starch degradation has been carried out by different approaches. The use of thermogravimetric analysis (TGA) has been widely used both for the determination of thermal stability and to evaluate the kinetics and mechanism of the degradation process of polymers. Analyses performed from a single curve or multiple curves provide information about the degradation mechanism, the activation energy of the reaction and the value of the factor pre-exponential (A), in addition to providing information on the existence or not of more than one stage of degradation (JANKOVIĆ, 2013; GUINESI et al, 2006).

In this sense, this work aims to characterize starch from different sources (corn, cassava and waxy maize) by intrinsic viscosity (capillary viscosity), amylose content, morphology (scanning electron microscopy, SEM) and crystallinity (XRD and FTIR). The starches used in this work are among those with the highest production and consumption and have distinct structural properties (amylose content, crystallinity and, viscosity), besides having a perspective of new technological applications. This work aims to evaluate the thermal degradation kinetics of these starches, seeking to deepen the understanding of the general mechanism of starch degradation during thermal processing and to evaluate the mechanism of non-isothermal degradation (thermogravimetric analysis (TGA)/derivative thermogravimetry (DTG), using different chemical reaction models and three different model-fitting techniques to evaluate the kinetics triplet $(E, \ln (A)$ and $n)$ : CoatsRedfern (COATS; REDFERN, 1964), Broido (BROIDO, 1969) and van Klevelen (VAN KREVELEN; VAN HEERDEN; HUNTJENS, 1951).

\section{Materials e Methods}

\section{Materials}

Commercial samples of waxy maize (ADS, MatãoSP), cassava starch (YOKI, Paranavaí-PR) and corn starch (MAIZENA, Garanhuns-PE) were used in this work. The starches were previously dried in an air circulating oven (Marconi-N1040) at $60^{\circ} \mathrm{C}$ for $24 \mathrm{~h}$, then kept in desiccators containing silica gel for at least 7 days before being analyzed. Amylose was acquired from Sigma-Aldrich (Lot \# SLBQ8195V), dimethyl sulfoxide (DMSO) and sodium hydroxide $(\mathrm{NaOH})$ were both acquired from Synth, Brazil.

\section{Methods}

The amylose content of the starch samples was measured from the method proposed by Hoover and Ratnayake (2001) using $4 \mathrm{~mL}$ of stock solution instead $1 \mathrm{~mL}$. Amylose content were determined using an analytical curve built with potato amylose $\left(R^{2}=0.998\right)($ Sigma-Aldrich) through the same procedure described for preparation of the starch samples. The viscosity $(\eta)$ was determined using the single point measurement (SOLOMON; CIUTA, 1962) by Ostwald-Fenske viscometer (Paragon Scientific Ltd-CFR 150). All the measurements were carried out in triplicate at $21.0 \pm 0.5{ }^{\circ} \mathrm{C}$ and using $0.5 \mathrm{~mol} . \mathrm{L}^{-1} \mathrm{NaOH}$. Morphological analysis of the starches was performed using a FEI Quanta 200 scanning electron microscope (Oregon, USA). The samples were covered with a thin layer of gold and the images were obtained using an acceleration voltage of $20 \mathrm{kV}$. Thermal stability of the starches was evaluated using the Perkin Elmer-TGA 4000 equipment. Samples (10-20 mg) were heated from 30 to $800{ }^{\circ} \mathrm{C}$ at a heating rate of $20{ }^{\circ} \mathrm{C} / \mathrm{min}$ under a nitrogen flow $50 \mathrm{~mL} / \mathrm{min}$. The ATR- FTIR analyses were performed on a Vertex $70 \mathrm{spec}-$ 
trophotometer, platinum, in attenuated total reflectance (ATR) mode with a resolution of $1 \mathrm{~cm}^{-1}$ and 16 scans in the range of 4000 to $400 \mathrm{~cm}^{-1}$. The relative crystallinity $(R c)$ of the starches was determined from FTIR data by using the ratio between the areas of the band at $1047 \mathrm{~cm}^{-1}$ (ordered band) and the bands at $1018 \mathrm{~cm}^{-1}$ (amorphous band), equation (1), obtained by deconvoluting the spectra in the range of $950-1100 \mathrm{~cm}^{-1}$ (SMITS et al., 1998),

$$
R c=A_{1047} / A_{1080}
$$

The position and number of peaks are checked by second derivative function of the original spectra.

The XRD measurements were carried out in a diffractometer (PANalytical-X'Pert PRO MPD) with pixel detector and $\mathrm{CuK} \alpha$ radiation, in the technique known as $\theta-2 \theta$, Bragg-Brentano geometry. The voltage and current used were, respectively, $40 \mathrm{KV}$ and $30 \mathrm{~mA}$. The $2 \theta$ scanning interval used varied from 2 to $120^{\circ}$ with an angular pitch of $0.05^{\circ}$. The counting time per point was $2 \mathrm{~s}$. In order to disregard possible preferential orientations in the sample preparation process, these samples were rotated cyclically during the measurement process over a period of $2 \mathrm{~s}$. The crystallinity index $(C I)$ was determined from the deconvolution of the diffractogram, according to Lopez-Rubio et al. (2008). The position and number of peaks were checked by second derivative function of the original diffractograms. The ratio of crystalline and amorphous area was determined from equation (2)

$$
C I=A c /(A c+A a),
$$

where $A c$ is sum of the area under the crystalline adjusted peaks, and $A a$ ?is the area of the amorphous halo.

\section{Kinetics of thermal degradation}

For a reaction in the solid state, the degree of conversion $(\alpha)$ can be obtained from a non-isothermal experiment and expressed as (HATAKEYAMA; QUINN, 1999):

$$
\alpha=\frac{m_{i}-m_{t}}{m_{i}-m_{f}}
$$

where $m_{t}$ is the mass at each instant at a temperature $\mathrm{T}$ (Kelvin), $m_{i}$ is the initial mass and $m_{f}$ is the final mass of the experiment. Substituting the Arrhenius equation in (3) and considering that the heating rate $\beta=d \alpha / d t$ of the thermogravimetric experiment is constant, the conversion rate is represented by equation (4)

$$
\frac{d \alpha}{d t}=K(t)=\frac{A}{\beta} \exp \left(\frac{-E_{a}}{R T}\right) f(\alpha)
$$

where $K(t)$ is the velocity constant, $f(\alpha)$ is the function that describes the conversion, $E_{a}$ is the activation energy; $A$ the pre-exponential factor; $R$ is the gas constant; $\beta=d \alpha / d t$ (heating rate) and $T$ is the absolute temperature.

Integrating (4) under non-isothermal conditions, we obtain equation (5)

$$
g(\alpha)=\int \frac{d \alpha}{f(\alpha)}=\frac{A}{\beta} \int \exp \left(\frac{-E_{a}}{R T}\right) d t
$$

Equation (5) cannot be expressed by a simple analytical form since its right-hand side corresponds to a series of infinite functions $g(\alpha)$. Differential, integral and approximate methods were developed to estimate non-isothermal kinetic parameters(HATAKEYAMA; QUINN, 1999) .

In this study the integral methods proposed by Coats and Redfern and Broido and the approximation methods proposed by and Van Krevelen were used (COAST; REDFERN, 1964; VAN KREVELEN et al., 1951; BROIDO, 1969). Using these methods, $A, E_{a}$ and $n$ can be estimate from a single curve or a series of thermogravimetric curves with different heating rates. These methods are based on the hypothesis that $A, E_{a}$ and $n$ characterize only a given reaction independently of the experimental conditions. Thus, by knowing the function $g(\alpha)$, we can determine the mechanism of the degradation process, the value of $A$ and $E_{a}$, determining the kinetic triplet of the thermal degradation process. In this work the mechanisms presented in Table 1 were evaluated.

The Coats-Redfern model, equation (6) in the Table 2, is one of the most widely used procedures for the determination of the reaction mechanism. In order to evaluate the reaction mechanism of non-isothermal degradation of starches, the equations proposed in Table 1 were tested and the model which provided the best fitting $\left(R^{2} \rightarrow 1\right)$ of the Coats-Redfern model was selected as the degradation mechanism (COATS; REDFERN, 1964). With the aid of this model, values of $E_{a}$ and pre-exponential factor $A$ of the Arrhenius equation were determined using the equations of Coats-Redfern, Broido, and van Krevelen (equations (6)-(8), in the Table 2), thereby determining the kinetic triplet. 
Table 1 - Algebraic expressions of $g(\alpha)$ for the kinetic models used (HOUSE, 2007)

\begin{tabular}{ll}
\hline Mechanism & $g(\alpha)$ \\
\hline$A_{2}$, Random Nucleation, Avrami Erofe' ev Equation & $(-\ln (1-\alpha))^{1 / 2}$ \\
$A_{3}$, Random Nucleation, Avrami Erofe' ev Equation & $(-\ln (1-\alpha))^{1 / 3}$ \\
$A_{4}$, Random Nucleation, Avrami Erofe' ev Equation & $(-\ln (1-\alpha))^{1 / 4}$ \\
$R_{1}$, unidimensional contraction & $\alpha$ \\
$R_{2}$, Cylindrical phase boundary & $(1-(1-\alpha))^{1 / 2}$ \\
$R_{3}$, Spherical phase boundary & $(1-(1-\alpha)) 1 / 3$ \\
$D_{1}$, One-dimentsonal diffusion & $\alpha^{2}$ \\
$D_{2}$, Two-dimensional diffusion (Valensi Equation) & $(1-\alpha) \ln (1-\alpha)+\alpha$ \\
$D_{3}$, Three-dimensional diffusion (Jander Equation) & $\left(1-(1-\alpha)^{1 / 3}\right)^{2}$ \\
$D_{4}$, Three-dimensional diffusion & $(1-(2 / 3) \alpha)-(1-\alpha)^{2 / 3}$ \\
$\quad$ (Ginstling-Brounshtein Equation) & $-\ln (1-\alpha)$ \\
$F_{1}$, First-order & $1 /(1-\alpha)$ \\
$F_{2}$, Second-order & $1 /(1-\alpha)^{2}$ \\
$F_{3}$, Third-order &
\end{tabular}

Source: HOUSE, (2007).

Table 2 - Mathematical models often used in solid state kinetic reactions (VAN KREVELEN et al., 1951; METZGER, 1963; COATS; REDFERN, 1964; BROIDO, 1969)

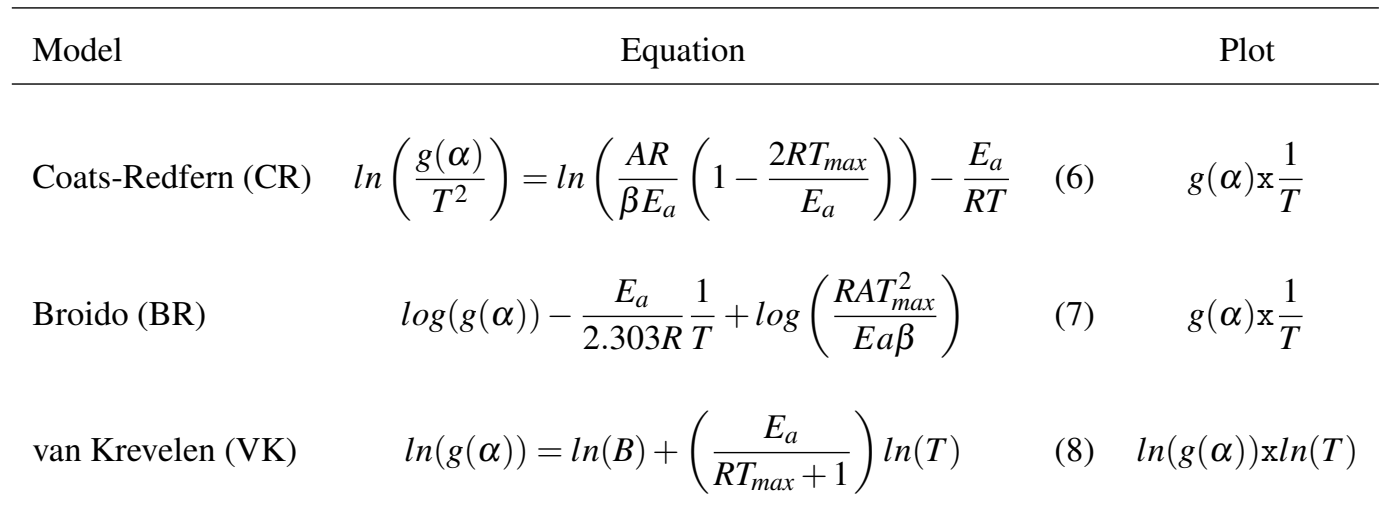

Source: VAN KREVELEN et al., (1951); METZGER, (1963); COATS; REDFERN, (1964); BROIDO, (1969).

In the Table 2, $T_{\max }$ is the temperature at maximum rate weight loss and $R$ is the universal gas constant (8.314 $\mathrm{J} / \mathrm{mol} \mathrm{K})$.

\section{Results and Discussion}

\section{SEM}

The morphologies of the starches can be observed in Figure 1. Cassava starch (Figure 1-a), present a rounded and smooth structure with some irregularities. Similar structures were observed by other authors (UTHUMPORN; ZAIDUL; KARIM, 2010). The corn starch (Figure 1-b) presented irregular polygonal morphology with random pores and roughness. The structure of the waxy maize starch (Figure 1-c) was like that of corn starch (Figure 1-b).

This is probably related to the fact that the waxy maize starch is produced from corn grains and the polygonal morphology in this starch is more rounded at the edges.

\section{Amylose content and intrinsic viscosity $(\eta)$}

The values determined for amylose content are shown in Table 3. The amylose contents were found to be 19.4, 30.1 and 0.0 for cassava, corn and waxy maize, respectively. The values agree with those found in the litera- 
Figure 1 - Scanning Electron Microscopy (SEM) images of cassava (a), corn (b) and waxy maize starch (c)

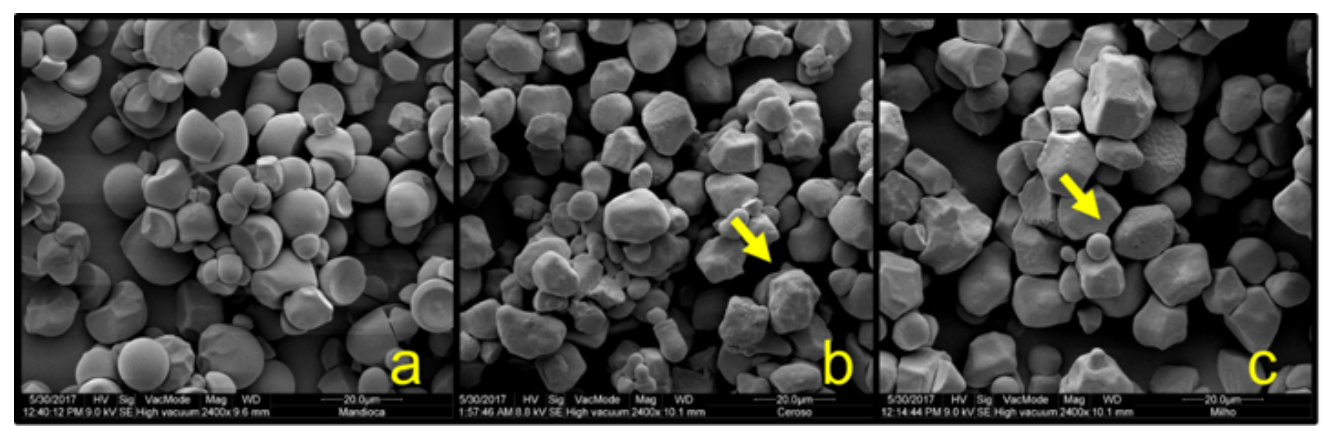

Source: The authors.

ture (VAN HUNG et al., 2012). The intrinsic viscosity of a polymer is a measure of the internal friction or resistance to displacement of molecules in solution, and it is related to the molecular mass, size and shape of the macromolecules. The values found for the intrinsic viscosities $\eta$, Table 3, of cassava, corn and waxy maize show a direct relationship between the amylose content and the viscosity. The highest value observed for intrinsic viscosity for starches with higher amylose contents is in accordance with the predicted from the information on the structure of the material. Amylopectin is a highly branched macromolecule, formed by short chains of approximately 15 glucose units, which decreases its ability to form tangles. Amylose is formed by long linear chains composed of 40 to 60 glucose units, favoring the formation of many entanglements.

\section{Ordered structure in starches}

The three starch samples showed similar FTIR spectra as well as all the characteristic bands for starches (Figure $2)$. Bands of higher intensities were noted between 3000$3600 \mathrm{~cm}^{-1}$ (O-H stretching) and at $995 \mathrm{~cm}^{-1}$ (COH bending vibrations). (KIZIL; IRUDAYARAJ; SEETHARAMAN, 2002) .

The Figure 3 shows the magnification of the region of the FTIR spectrum between 900 and $1100 \mathrm{~cm}^{-1}$. For a better analysis of the contributions of the bands at 1022 and $1047 \mathrm{~cm}^{-1}$, these bands were separated using a Gaussian function. Curve and $R c=A_{1047} / A_{1022}$ values were determined, Table 3. It was observed no significant difference (Tukey < 0.05 ) in the $R c$ value for the three starches, thus indicating that the source, the amylose content and viscosity do not influence this parameter for the studied starches.

Figure 4 shows the diffractograms for the three starch sources studied. It is observed that all the samples present characteristic X-ray diffraction peaks for type A poly-
Figure 2 - ATR-FTIR spectra of cassava, corn and waxy maize starch samples. Mark: region from 900 to 1100 $\mathrm{cm}^{-1}$ showing deconvoluted bands at 1022, 995 and 1045 $\mathrm{cm}^{-1}$

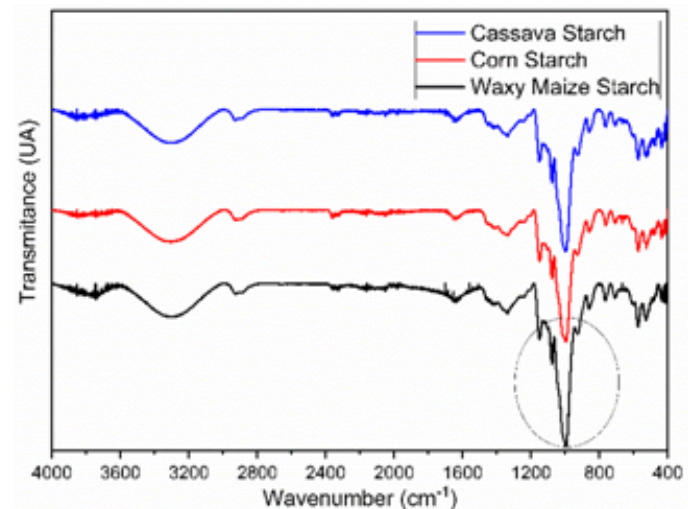

Source: The authors.

Figure 3 - ATR-FTIR spectra of maize starch samples. Showing deconvoluted bands at 1022, 995 and $1045 \mathrm{~cm}^{-1}$

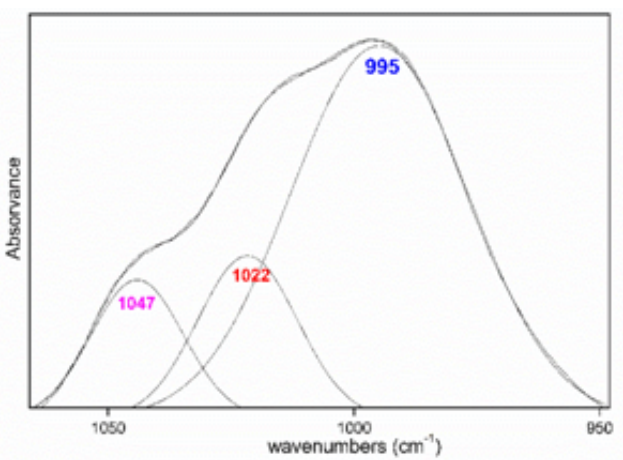

Source: The authors.

morph. The $C I$ of the starches were determined from the deconvoluted diffractograms, Figure 5. The obtained values of $C I$ are presented in Table 3.

The obtained values of $C I$ showed a significant difference (Tukey, $\mathrm{p} \leq 0.05$ ). It is observed that the crystallinity is lower for samples with higher amylose content and higher viscosity, Table 3 . The relation between amylose content and short- and long-range crystallinity is a controversial topic. While some authors claim the existence of a relation, other authors have found that these two parame- 
Table 3 - Results obtained for amylose content and intrinsic viscosity, $R c$ values obtained by ATR-FTIR (short-rangeorder) and $C I$ values obtained by XRD (three-dimensional-ordering) measurements of starches for cassava, corn and waxy maize starches

\begin{tabular}{lccc}
\hline & \multicolumn{3}{c}{ Starch } \\
\cline { 2 - 4 } & Cassava & Corn & Waxy Maize \\
\hline Amylose (\%) & $19.4 \pm 0.3^{b}$ & $30.1 \pm 1.4^{a}$ & $0.0 \pm 0.0^{c}$ \\
$\eta$ & $0.619 \pm 0.004^{b}$ & $1.072 \pm 0.004^{a}$ & $0.543 \pm 0.011^{c}$ \\
$R c=A_{1047} / A_{1022}$ & $0.88 \pm 0.07$ & $0.91 \pm 0.06$ & $0.94 \pm 0.12$ \\
$C I$ & $31.4 \pm 0.8$ & $28.6 \pm 1.1$ & $33.5 \pm 0.9$ \\
\hline
\end{tabular}

Mean \pm standard deviation. Values in different letters in the same column indicate significant difference between samples (Tukey test, $\mathrm{p} \leq 0.05$ ).

Source: The authors.

Figure 4 - Diffractograms of cassava, corn and waxy maize starch samples

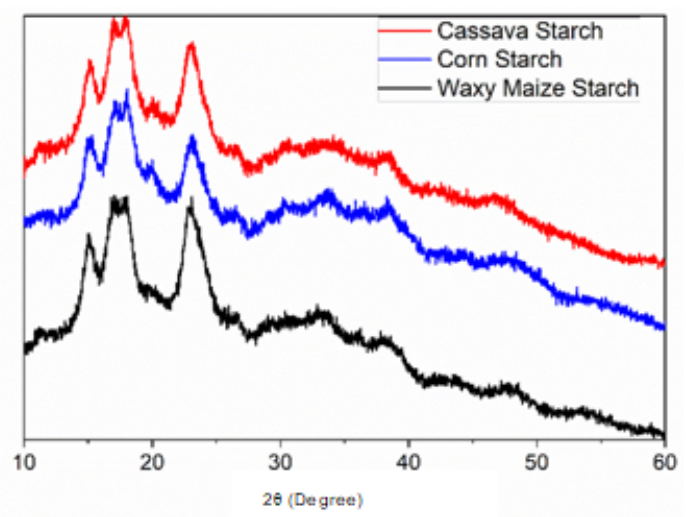

Source: The authors.

ters are not related. This lack of agreement may be resulted from the techniques used to determine the amylose content and the mathematical models used to determine the crystallinity by XRD or FTIR. The deconvolution of the peaks and bands can be carried out using different functions and the position and the number of peaks considered to obtain the adjustment must be considered, as well as the baseline tracing. In this work, Gaussian functions were used for deconvolution and the number and position of the bands was determined based on the literature and from the second derivative of the original curve, allowing the exact location of the quantity and position of each peak.

In this study the FTIR-ATR technique was not sensitive to determine differences between the short-range ordering of the analyzed samples, Table 3 , and it is not possible to conclude how the amylose content influences in the short-range ordering and correlate with the crystallinity data obtained by XRD. However, the long-range order data obtained by XRD (Table 3 ) are statistically different, being possible the relationship of $C I$ with the amylose content (CHEN et al., 2006).
Figure 5 - Deconvoluted diffractograms of cassava, waxy maize and corn starch for determination of the crystallinity index (CI): a) Cassava Starch; b) Corn Starch; c) Waxy maize Starch
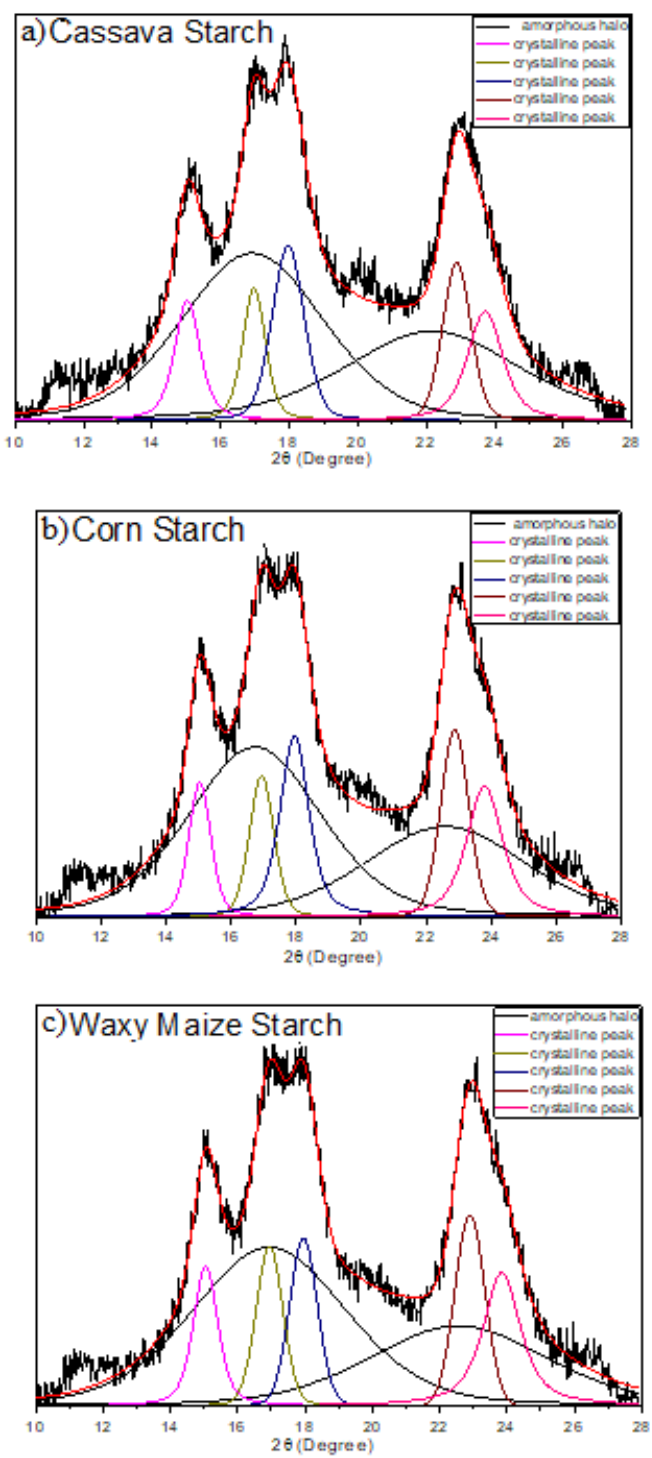

Source: The authors 
$T G A$

The TGA/DTGA curves for corn, waxy maize and cassava starches are presented in Figure 6. The three starch sources presented thermogravimetric curves with similar profile. The $T_{\max }$ values were found to be 337, 329 and $327{ }^{\circ} \mathrm{C}$ for cassava, corn and waxy maize starches, respectively. A mass loss of approximately 5.90\%, 8.30\% and $7.23 \%$ was observed at $150{ }^{\circ} \mathrm{C}$ for cassava, corn and waxy maize starches, respectively, associated with loss of water and compounds of low molecular weight present in the samples.

Figure 6 - TGA/DTGA curves for cassava, corn and waxy maize starches
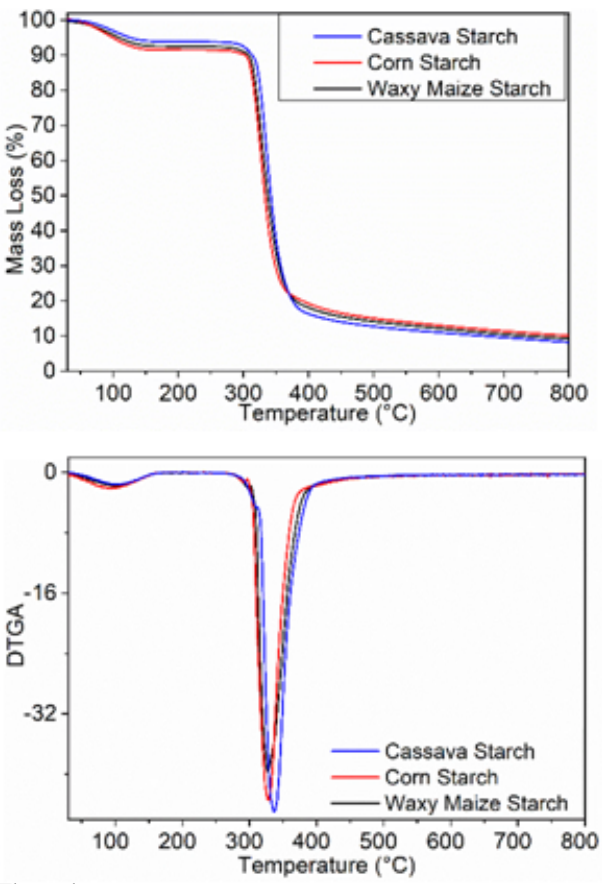

Source: The authors.

The second step observed between 300 and $400{ }^{\circ} \mathrm{C}$ is related to the release of hydroxyls groups leading to depolymerization and degradation. In this temperature range a series of irreversible changes occur, with formation of soluble products in cold water, denominated pyrodextrin, depolymerization of macromolecules with the formation of D-(1,6) anhydrous-D-lucopyranose (levoglucan), 2-furaldehyde (furfural) and low molecular weight gaseous products. Around $400{ }^{\circ} \mathrm{C}$, after the release of all volatile products, a carbonaceous residue is remained (AGGARWAL; DOLLIMORE, 1998). Regarding the residual mass $(\%)$ at $800{ }^{\circ} \mathrm{C}$, the starch with the highest percentage was the one from corn, with $10.13 \%$, followed by waxy maize with $9.26 \%$ and cassava with $8.21 \%$.
The crystallinity (XRD) and amylose content influence the Ea values of the samples: the wazy corn sample with higher amylopectin content has higher Ea values. This behavior can be justified by the higher molar mass and greater stability of amylopectin (LIU et al., 2013). The similarity in the profile of the TGA curves can be related to the thermal degradation of the amylose and amylopectin components occurring in the same temperature range (327$337^{\circ} \mathrm{C}$ ), Figure 5 , may be due the similarities in their morphology, causing the events to overlap and the separation difficult. In this work the second derivative method was used to identify the temperature and the number of events during the thermal degradation of the starches, and the presence of only one event in the temperature range of 327-337 ${ }^{\circ} \mathrm{C}$ was detected.

\section{Kinetics of thermal degradation study}

The study of thermal degradation kinetics of the starches from the TGA data was performed by applying the equation proposed by Coats-Redfern, equation (6), for determination of the reaction mechanism, Table 1 . Model fitting method was applied and the $R^{2}$ values are presented in Table 4.

Table $4-R^{2}$ values determined from mechanisms proposed in Table 1

\begin{tabular}{cccc}
\hline Mechanism & \multicolumn{3}{c}{$R^{2}$} \\
\cline { 2 - 4 } & Waxy Maize & Cassava & Corn \\
\hline A2 & 0.99168 & 0.990440 & 0.99649 \\
A3 & 0.99135 & 0.98988 & 0.99628 \\
A4 & 0.99101 & 0.98927 & 0.99605 \\
R1 & 0.97091 & 0.96226 & 0.98211 \\
R2 & 0.96945 & 0.95926 & 0.98057 \\
R3 & 0.96787 & 0.95591 & 0.97883 \\
D1 & 0.97160 & 0.96364 & 0.98281 \\
D2 & 0.97966 & 0.97451 & 0.98857 \\
D3 & 0.97019 & 0.96080 & 0.98136 \\
D4 & 0.98243 & 0.97834 & 0.99054 \\
F1 & 0.99199 & 0.99096 & 0.99669 \\
F2 & 0.96038 & 0.96150 & 0.98313 \\
F3 & 0.96159 & 0.96292 & 0.98370 \\
\hline
\end{tabular}

Source: The authors.

From the data shown in Table 4 the mechanisms $A_{2}$ and $F_{1}$ presented the coefficient of determination $\left(R^{2}\right)$ closest to unity. Considering that degradation of starch occurs in one stage, the first-order mechanism was chosen indicating that instantaneous nucleation and one-dimensional growth controls the degradation mecha- 
Merci, A.; Mali, S.; De Carvalho, G.M.

Table 5 - Activation energy $\left(E_{a}\right)$ and the pre-exponential factor $(A)$ determined using the methods of Broido (BR), Coats-Redfern (CR) and van Krevelen (VK)

\begin{tabular}{|c|c|c|c|c|c|c|c|c|c|}
\hline \multirow{3}{*}{ Model } & \multicolumn{3}{|c|}{$\mathrm{A}\left(\mathrm{s}^{-1}\right)$} & \multicolumn{3}{|c|}{$\mathrm{E}_{a}(\mathrm{KJ})$} & \multicolumn{3}{|c|}{$R^{2}$} \\
\hline & Waxy & Cassava & Corn & Waxy & Cassava & Corn & Waxy & Cassava & Corn \\
\hline & Maize & & & Maize & & & Maize & & \\
\hline Broido & $5.8 \times 10^{49}$ & $4.6 \times 10^{34}$ & $3.0 \times 10^{34}$ & 551.8 & 388.7 & 381.6 & 0.99228 & 0.99144 & 0.99686 \\
\hline v. Krevelen & 0 & 0 & 0 & 549.9 & 383.8 & 379.9 & 0.99187 & 0.99081 & 0.99660 \\
\hline Coats- & $5.3 \times 10^{47}$ & $4.0 \times 10^{32}$ & $2.6 \times 10^{32}$ & 541.2 & 378.5 & 371.3 & 0.99199 & 0.99096 & 0.99669 \\
\hline Redfern & & & & & & & & & \\
\hline
\end{tabular}

Source: The authors.

nism for all starches. The activation energy determined represents an average value of the degradation process. This assumption was confirmed by the second derivative of TGA curves, that presented only one inflection point.

Once the control mechanism of the degradation reaction kinetics was defined, the activation energy $\left(E_{a}\right)$ and the pre-exponential factor $(A)$ were determined using the methods of Broido (BR), Coats-Redfern (CR) and van Krevelen (VK). These methods differ only in the mathematical approach used to solve the Arrhenius equation. The use of the different models is recommended to corroborate the resulting kinetic parameters, considering that the different approaches used lead to systematic errors in the values of the activation energy and the pre-exponential factor. The model-fitting and isoconversional mathematical models are well established for the determination of the activation energy of polymeric materials (HATAKEYAMA; QUINN, 1999). The values of Ea obtained by the isoconversional models for starch from different sources (PINEDA-GOMES et al., 2014; JANCOVIC, 2014; LIU et al., 2019) (170 to $200 \mathrm{~kJ} / \mathrm{mol})$ are below the values found in this work $(380-550 \mathrm{~kJ} / \mathrm{mol})$. This difference is due to the mathematical approximations used in each method.

The values of activation energy, determined for each starch using the three proposed models, result in similar values, meaning that all the methods can be used to obtain a correct approach, Table 4 . The waxy maize starch presented higher $E_{a}$ values when compared to the values obtained for cassava and corn starches, which presented similar values, Table 5 . It is noted a relation between the values of $E_{a}$, crystallinity and amylopectin content, being observed the order: waxy maize $>$ cassava $>$ corn, indicating that structural factors such as ramifications and ordering influence the thermal degradation process.

\section{Conclusion}

In this study, starch from different sources (corn, cassava and waxy maize) were characterized and the degradation mechanisms were evaluated using different reaction models and three different model-fitting techniques to evaluate the kinetics triplet ( $E, A$, and $\mathrm{n}$ ). The FTIR technique was not sensitive to short-range arrangement present in the starches, whereas XRD technique made it possible to identify differences in the long-range order. The results achieved indicated that the kinetic triplet $(E, A$ and $g(\alpha))$, can be obtained satisfactory. Using the Coats-Redfern model, it was determined that the degradation process mechanism is first-order.

There are significant differences between the values of the kinetic triplet of the starches, indicating that structural differences can influence on the thermal degradation process of the starches. The results of intrinsic viscosity, crystallinity index (XRD) and activation energy of the degradation process are related to the amylose content of the studied starches. The corn starch presented higher values of amylose content and viscosity, followed by lower crystallinity (long-range order) and Ea values. The waxy maize starch had the lowest values of amylose content and viscosity and the highest values of crystallinity (long-range order) and activation energy. Cassava starch presented intermediate values to those observed for corn and waxy maize starches (amylose content, crystallinity, activation energy and viscosity).

The $E_{a}$ values calculated for starch thermal degradation using different kinetic models reveal that the use of $\mathrm{BR}, \mathrm{CR}$ and $\mathrm{VK}$ models result in similar activation energies for each starch, which means the methods are comparable. 


\section{Acknowledgments}

This study was financed in part by the Coordenação de Aperfeiçoamento de Pessoal de Nível Superior - Brasil (CAPES) - Finance Code 001.The authors would like to thank the Conselho Nacional de Desenvolvimento Científico e Tecnológico (CNPq - Brazil), and Fundação Araucária - Brazil for their financial support, and also the LARX and LMEM Laboratories (CMLP - UEL).

\section{References}

AGGARWAL, P.; DOLLIMORE, D. A thermal analysis investigation of partially hydrolyzed starch. Thermochimica Acta, v. 319, n. 1-2, p. 17-25, 1998. Available from internet: <http://www.sciencedirect.com/ science/article/pii/S0040603198003554>.

BROIDO, A. A simple, sensitive graphical method of treating thermogravimetric analysis data. Journal of Polymer Science Part A-2: Polymer Physics, v. 7, n. 10, p. 1761-1773, 1969. Available from internet: <http://doi.wiley.com/10. 1002/pol.1969.160071012>.

CHEN, P.; YU, L.; CHEN, L.; LI, X. Morphology and Microstructure of Maize Starches with Different Amylose / Amylopectin Content. Starch/Stärke, v. 58, p. 611-615, 2006.

COATS, A. W.; REDFERN, J. P. Kinetic parameters from thermogravimetric data. Nature, n. 201, p. 68-69, 1964.

GUINESI, L. S.; DA RÓZ, A. L.; CORRADINI, E.; MATTOSO, L. H. C.; TEIXEIRA, E. M.; CURVELO, A. A. S. Kinetics of thermal degradation applied to starches from different botanical origins by non-isothermal procedures. Thermochimica Acta, Amsterdam,v. 447, p. 190 - 196, 2006.

HATAKEYAMA, T; QUINN, F.X. Thermal Analysis Fundamentals and Applications to Polymer Science. 2. ed. [s.l: s.n.]

HOUSE, J. E. Principles of Chemical Kinetics. 2. ed. [s.1.] Academic Press is an imprint of Elsevier, 2007.

HOOVER, R.; RATNAYAKE, W. S. Determination of total amylose content. Current Protocols in Food Analytical Chemistry. [s.1: s.n.]p. E2.3.1-E2.3.5, 2001. <https: //doi.org/10.1002/0471142913.fae0203s00>.
JANKOVIĆ, B. Thermal characterization and detailed kinetic analysis of Cassava starch thermo-oxidative degradation. Carbohydrate Polymers, v. 95, p. 621-629, 2013.

KIZIL, R.; IRUDAYARAJ, J.; SEETHARAMAN, K. Characterization of Irradiated Starches by Using FTRaman and FTIR Spectroscopy. Journal of Agricultural and Food Chemistry, v. 50, p. 3912-3918, 2002.

LIU, X.; WANG, Y.; YU, L.; TONG, Z.; CHEN, L.; LIU, H.; LI, X. Thermal degradation and stability of starch under different processing conditions. Starch/Stärke, v. 65, n. 1-2, p. 48-60, 2013.

LIU, X.; YU, L.; XIE, F.; LI, M.; CHEN, L.; LI, X. Kinetics and mechanism of thermal decomposition of cornstarches with different amylose/amylopectin ratios. Starch/Stärke, v. 62, n. 3-4, p. 139-146, 2010.

LIU, Y.; YANG, L.; MA, C.; ZHANG, Y. Thermal behavior of sweet potato starch by non-isothermal thermogravimetric analysis. Materials, Basel, v.12, n.5, p.699, 2019.

LOPEZ-RUBIO, A.; FLANAGAN, B. M.; GILBERT, E. P.; GIDLEY, M. J. A Novel Approach for Calculating Starch Crystallinity and Its Correlation. Biopolymers, v. 89, n. 9, p. 761-768, 2008.

MERCI, A.; MARIM, R. G.; URBANO, A.; MALI, S. Films based on cassava starch reinforced with soybean hulls or microcrystalline cellulose from soybean hulls. Food Packaging and Shelf Life, [s.1.], v. 20, p. 100321, apr. 2019. <https://doi.org/10.1016/j.fpsl.2019.100321>.

METZGER, H. M. H. G. A New Analysis of Thermogravimetric Traces. Analytical chemistry, v. 35, n. 10, p. 1464-1468, 1963.

PINEDA-GÓMEZ, P. ; ANGEL-GIL, N. C ; VALENCIAMUÑOZ, C. ; ROSALES-RIVERA, A. ; RODRÍGUEZGARCÍA, M.E. Thermal degradation of starch sources: Green banana, potato, cassava, and corn - kinetic study by non-isothermal procedures. Starch/Stärke, v.66, n.7/8, p.691-699, 2014.

REIS, M. O.; OLIVATO, J. B.; BILCK, A. P.; ZANELA, J.; GROSSMANN, M. V. E.; YAMASHITA, F. Biodegradable trays of thermoplastic starch/poly (lactic acid) coated with beeswax. Industrial Crops and Products, v. 112, n. January, p. 481-487, 2018. Available from internet: <https://doi.org/10.1016/j.indcrop.2017.12. 045.> 
SMITS, A. L. M.; RUHNAU, F. C.; VLIEGENTHART, J. F. G.; VAN SOEST, J. J. G. Ageing of Starch Based Systems as Observed with FT-IR and Solid State NMR Spectroscopy. Starch/Stärke, v. 50, n. 11-12, p. 478-483, 1998.

SOLOMON, O. F.; CIUTA, I. Z. Determination de la viscosite intrinseque de solutions de polymeres par une simple determination de la viscosite. Journal ofApplied Polymer Science, v. VI, n. 24, p. 683-686, 1962.

UTHUMPORN, U.; ZAIDUL, I. S. M.; KARIM, A. A. Hydrolysis of granular starch at sub-gelatinization temperature using a mixture of amylolytic enzymes. Food and Bioproducts Processing, v.88, n.1, p.47-54, 2010. Available from internet:<http://dx.doi.org/10.1016/j.fbp.2009. 10.001.>
VAN HUNG, P.; LAN PHI, N. T.; VY VY, T. T. Effect of debranching and storage condition on crystallinity and functional properties of cassava and potato starches. Starch/Stärke, v. 00, p. 1-8, 2012.

VAN KREVELEN, D. W.; VAN HEERDEN, C.; HUNTJENS, F. J. Physicochemical aspects of the pyrolysis of coal and related organic compounds. Fuel, v. 30, p. 253, 1951.

VAN KREVELEN, D. W.; VAN HEERDEN, C.; HUNTJENS, F. J. Physicochemical aspects of the pyrolysis of coal and related organic compounds. Fuel, London, v. 30, p. $253,1951$. 